\title{
Analysis of the Mixed Teaching Mode of College English under the Network Environment
}

\author{
Qing Wei
}

School of Foreign Studies, Xi'an University, 710065

\section{Keywords: Network Environment; College English; Mixed Teaching Mode; Analysis}

\begin{abstract}
With the continuous development of society, Chinese education reform also continues to advance. At present, there is a high degree of concern for the traditional and modern combination of mixed teaching mode. The mixed teaching mode of English not only has flexible and high quality, but also can promote students' initiative to learn English and to enhance students' English level. This paper expounds the theoretical basis and basic content of the mixed teaching mode under the network environment, analyzes the necessity of using the mixed teaching mode of English, and puts forward the empirical research steps of the mixed teaching mode under the network environment. Finally, the mixed teaching mode of English is analyzed to enhance the quality of English teaching and students' English level.
\end{abstract}

\section{Introduction}

With the continuous development of society and the continuous improvement of information technology, information technology gradually penetrates into people's daily life and learning. English teaching and learning is no exception. English teaching and learning should be advanced with the times. The traditional teaching mode which treats teachers as the main body cannot keep up with the development of the times and the continuous improvement of English teaching needs, while teachers cannot be a good guide and supervision when uses modern network teaching mode. Whether it is the traditional teaching mode or the modern network teaching mode cannot guarantee the quality of English teaching, the mixed teaching mode which combines traditional teaching and network teaching come into being for solving this problem. In the mixed teaching mode under the network environment, the student is the main body of learning and teachers play a guiding role. The following will be a simple analysis and discussion of this emerging teaching mode.

\section{Theoretical Basis of Mixed Teaching Mode under the Network Environment}

Humanistic Psychology School. Humanistic learning philosophy holds that knowledge is the embodiment of the internal structure of the main body, and learning can promote the individual's personal values, temperament, and potential. This concept attaches great importance to the individual emotions and personal ideas during learning. Humanistic psychology advocates that students are the subject of teaching in education and focuses on the development of students' self-concept. This concept holds that students should learn in an equal, relaxed and pleasant atmosphere. In teaching, teachers are responsible for the proper and timely guidance of students and advocate students' independent learning knowledge. Students can work independently or cooperate with other students to develop learning programs and learning evaluation, in order to achieve a real student-centered learning mode.

Constructivist View of Modern Cognitive Psychology. Constructivism was widely popular as early as 1990, and constructivism was a category in cognitivism. Constructivism argues that knowledge is the product of an individual's reaction in the external environment and the internal environment. The individual can get knowledge from learning and they can also get knowledge with the help of information, materials or teaching from other individuals in a particular environment and circumstances. On the one hand, learning is the individual instinctive trend of the behavior; on the other hand, it is the individual cognitive reconstruction. Constructivism argues that teachers are not only responsible for teaching knowledge, but also helpful for students to build 
knowledge as knowledge construction is an important component of learning. At this stage, constructivism theory is an important guide and direction in English teaching reform.

It is argued that the basis of individual learning language is the understanding of voice input, and the important basis for understanding language input is the language environment. Therefore, in English teaching, teachers can use information technology to create a good language environment for students, and thus promote students' enthusiasm and interest in learning to promote the construction of students' knowledge. Students can use network information and other educational resources to further master and digest the language knowledge, so as to further mobilize the enthusiasm of learning and enhance the level of language use.

\section{Basic Content of Mixed Teaching Mode under the Network Environment}

With the continuous development of society and the continuous improvement of the level of information technology, network teaching resources and information is also increasingly rich and systematic. Based on today's network environment, constructivism learning and humanistic learning can complement each other and form a new type of teaching mode. In terms of language teaching, the network teaching can provide audio, video, pictures and other learning resources, which can effectively improve the quality of teaching and student interest in learning. The kinds of network teaching resources can fully meet the needs of various language environments, so as to build a good learning atmosphere and mobilize the enthusiasm of students to make students more focused to absorb and master the knowledge.

Students are the main body of learning in this teaching mode. The mixed teaching mode under the network environment is divided into the following modes: mixed learning mode, learning mode under the network environment, cooperative learning mode and autonomous learning mode. This kind of teaching mode is a very good combination of network learning, cooperative learning, autonomous learning and traditional teaching. In this teaching mode, the teacher's supervision and guidance of students has been a very good expression. In addition, this teaching mode also has greatly improved students' self-learning awareness, creative thinking and learning initiative. Mixed teaching mode with network teaching information and resources provide students with a richer and more flexible way of learning, so that students can design their own learning plans and learning content. Through the network, students can communicate with teachers and teachers can also guide students to learn.

\section{Analysis of the Necessity of Mixed English Teaching Mode}

The Present Situation and Problems of English Teaching Mode. The vast majorities of traditional English teaching modes are based on the book, only focus on the theoretical knowledge teaching and ignore to develop the comprehensive ability of students, leading to serious problems between teachers and students. In the traditional teaching mode, teachers teach students the knowledge on books in the classroom and students can only passively accept the knowledge. This kind of teaching mode leads to serious problems in the quality of teaching. Students' ability of innovation and self-thinking cannot get exercise and students cannot use the knowledge flexibly. The current English teaching model ignores the ability to cultivate students' practical English, and students can learn English but cannot use English flexibly. During learning, students are forced to learn and remember the knowledge in stereotype, which made students lose the joy and enthusiasm of learning. In fact, students will tired and contradicted to learn English if they cannot exercise the practical ability of English during English learning. Finally, they will lose the desire to learn English over time and cannot really realize the students' autonomous learning. As current English teaching is filled with all kinds of examinations, students have to be subject to various types of test oppression from the beginning of the study, causing English teaching oriented to examination. Teachers are more focused on the inculcation of the textbook knowledge in the classroom and blindly let the students master the test content, rather than focus on the practical application ability of students. Under the influence of such teaching, students who study English tend to write rather 
than say, which make students' English application ability poor.

In addition, on the one hand, the rapid development of information technology led that the network educational information resources are more and more diversified, on the other hand it also provides online communication platform for teachers and students. Besides, the network video teaching, CD teaching and other resources teaching methods emerge in endlessly, which led the traditional teaching mode faced challenge once again. Actually, students learn by themselves through the network teaching mode may not have a good effect if they are lack of teachers' guidance and supervision.

Analysis of the Necessity of Mixed English Teaching Mode. Through the analysis of the shortcomings of the traditional teaching mode, it is easy to see that the students' mastery and application of English are not improved and the quality of English teaching is not well, which has a great limit for the improvement and development of English teaching quality in the traditional teaching mode. Therefore, teachers should actively reform the traditional English teaching methods to combine it with the network teaching together by using the network as a medium. The main body of the traditional teaching mode is the teacher and the main body of the network teaching mode is the student. The two kinds of teaching modes are combined into a new type of mixed teaching mode, which can solve the problem of insufficient practical use of English and the lack of guidance and supervision of teachers. In fact, the mixed teaching mode has indeed achieved satisfactory results in the practical application of some regions in recent years. This kind of teaching mode has played a significant role for the improvement of English teaching.

\section{Empirical Research Steps of the Mixed Teaching Mode under the Network Environment}

The implementation of mixed English teaching mode under the network environment is the inevitable trend of the development of the times, which can effectively improve the quality of English teaching and students' comprehensive level of English. The specific implementation of the mixed teaching mode should be a good combination of various teaching modes and make rational use of the advantages of each teaching mode. At the same time, the teacher is responsible for guiding students' learning, focuses on cultivating students' English practical application ability and self-learning consciousness and enhances students' enthusiasm for learning. In the teaching process, teachers should act as a good guide with the help of a wide range of diversified network teaching resources, on the one hand to mobilize the enthusiasm of students, on the one hand to urge students to learn. Specific practice steps are as follows.

Experimental Subject. Students who study college English should be chose as the subjects in this experiment. Taking two classes, which have similar learning atmosphere, performance and grade, as the experimental subject and reference subject, and the reference subject has no changes in the teaching mode, while the experimental subject use the network mixed English teaching mode. Through one year experiment, the teaching results of the reference subject and the experimental subject can be tested and compared. And according to the results of the test and comparison, researchers can determine whether the network mixed English teaching mode can improve the quality of college English teaching, and analyze the gap of teaching results between network mixed English teaching mode and the traditional teaching mode.

Experimental Variable. Three variables need to be controlled in the experiment. The first is the dependent variable, that is to say, students' autonomous learning ability, knowledge application ability and learning achievement. The second is the independent variable, that is to say, the teaching methods used by teachers, respectively are the network mixed English teaching mode and the traditional teaching mode. Finally is the interference variable, that is to say, the learning environment, the students' English level, teachers and students personal emotions.

Experimental Course. The main content of the experimental course is the teaching material in New Horizon College English, and then the teaching is carried out with other network teaching information resources. Students can view the teaching content and teaching plan through the network, can also submit homework, communicate with the teacher and practice their listening with the help of multimedia teaching resources, etc. Teachers can guide and supervise students through 
the network as well as change the learning content, etc. to provide an important guarantee for the quality of teaching.

The Implementation of Mixed Teaching Mode under Network Multimedia Environment. By means of the network, the implementation of combination of the traditional teaching mode and the network mixed English teaching mode is as follows. First, combining online teaching with students' independent learning together, students can search for the necessary educational information resources through the network and self-learning, training their listening, speaking skills and written expression in the network, and then, to cultivate the students' comprehensive skills and the practical application ability of English. Second, combining network teaching and traditional teaching mode together, so that students can firstly find resources of self-learning through the network, and then they can consult teachers. Teachers are responsible for answering doubts summing up the knowledge for students, and then organize students to practice oral English according to their knowledge to deepen their understanding and master the knowledge, so as to improve students' comprehensive level of English.

\section{Summary}

To sum up, the traditional teaching mode puts emphasis on the theoretical knowledge too much, which cannot promote students' ability of innovation and self-thinking. Meanwhile, the independent network learning is lack of teacher's guide to supervise students. Therefore, researchers should actively promote the mixed teaching mode which combines traditional teaching and network teaching to enhance the quality of English teaching and students' comprehensive level of English. By selecting the appropriate experimental subjects, controlling the experimental variables, planning the experimental course and carrying out the mixed teaching experiment, teachers can apply the mixed teaching mode of college English flexibly in the actual teaching under the network environment. Network multimedia teaching, cooperative learning, self-learning and traditional teaching can be combined together with the help of network, and then the advantages of various teaching models can be integrated to build a mixed teaching mode with superior teaching effectiveness. Finally, the comprehensive level of English will be improved and the level of college English teaching will be enhanced, so as to meet the needs for high-quality English professionals.

\section{Reference}

[1] B.J. Liu and B. Yang. Teaching Mode of Discourse Analysis of Intensive Reading Course for College English Majors under the Network and Multimedia Teaching Environment[J]. Journal of Shenyang University (Social Science Edition), 2014, 01: 84-87.

[2] Y. Guo and L. Bai. Research on the Innovation of Teaching Methods of Ideological and Political Education in Colleges and Universities under the Network Environment - The Enlightenment of Muji to the Reform of Teaching Mode[J]. Modern Education Science, 2014, 11: 61-64+69.

[3] J.F. Zhu. Constructing Mixed Teaching Mode of Master 's English Course in Medical Colleges and Universities under the Network Environment[J]. Journal of Nanjing Medical University (Social Science Edition), 2013, 05: 465-467.

[4] L.J. Jiang. On the Integration of Network Information Technology and Foreign Language Teaching Design - Comment on "An Introduction to the Integration of Network Environment and College English Course"[J]. Chinese Journal of Education, 2016, 10: 147.

[5] N. Li, Y. Zhang and C.F. Zhou. The Current Situation and Reform of English Extensive Reading in Colleges and Universities under the Network Environment - Based on the Investigation of Three Gorges University[J]. Drama Home, 2015, 13: 226-227.

[6] T.G. Gao, S.W. Ren, L.M. Wang and K. Xiao. Research on Mixed Teaching Mode of Applied Talents Cultivation in Universities under MOOCs Environment[J]. Higher Education of Science, 2015, 01: 101-105.

[7] J. Liu. The Function and Quality Requirement of College English Teachers under the Mode of "Dual Master" Network Teaching[J]. Journal of Hunan Agricultural University (Social Science 
Edition. Quality Education Research), 2008, 01: 95-96+99.

[8] Y.L. Deng. The Application of Three-dimensional Teaching Mode in the Teaching of English Listening and Speaking under the Network Environment - An Analysis of the Construction of the National Excellent Course in English Listening and Speaking[J]. Foreign Language and Foreign Language Teaching, 2009, 11: 25-27+31.

[9] Q. Guo and Y.M. Gao. Taking the Combination of Multimedia Network Teaching and Classroom Teaching - A Study on the Transformation Mode of Intensive Reading Course for English Majors in Colleges and Universities[J]. Foreign Language Teaching in Shandong Province, 2006, 04: 17-21.

[10] Y.H. Zhuang. Exploring the New Mode of Large Class Teaching in College English Listening and Speaking Course in Network Teaching Environment[J]. Journal of Hubei Radio \& TV University, 2012, 06: 133-134.

[11]Z.H. Shang. A Probe into the Teaching Mode of English Writing Network - The Application of Process Genre Teaching Method in Multimedia and Network Environment[J]. Journal of Distance Education, 2008, 03: 45-48+17.

[12] X.B. Zhu, T. Li and Y.C. Tao. College English Interpreting Teaching Mode and Resource Construction under Information Environment[J/OL]. Journal of Liaoning University of Technology (Social Science Edition), 2016(02). 